\title{
A Development of Web Based John Holland Theory Career Interest Detection Instruments
}

\author{
Nararya Rahadyan Budiyono* \\ Program Studi Bimbingan dan Konseling \\ Universitas Teknologi Yogyakarta \\ Sleman, Indonesia \\ nararya@uty.ac.id*
}

\begin{abstract}
Self-understanding is the first and foremost step in the career decision-making process. Failure in a career begins with inability to recognize and identify career potentials and interests, and has an impact on mistakes in majoring in school or college. This paper is an idea of a research plan that was built from the background of student problems at Yogyakarta University of Technology. Research and development methods are chosen to create instrument products that are able to detect one's career interests. The planning final product is the form of a website and uses John L. Holland's career theory as the basis for product development. The main idea of this product is to help users recognize the characteristics of career and work interests or positions that match their qualifications. Therefore users are able to achieve optimal career achievement.
\end{abstract}

Keywords- career decision making, instrument of interest identification, John L. Holland's career theory

\section{INTRODUCTION}

Throughout human life span, career achievement is one of everyone's orientations. In general, Winkel and Hastuti ${ }^{[1]}$ explain the notion of a career as a journey that covers all aspects of one's life. There are three aspects of life in a career context, namely (a) life role, (b) environment (life setting), (c) life event. According to Mathis and Jakson [1], a career is a sequence of positions related to one's occupation throughout his life. Careers are work-related experiences that span throughout the work journey experienced by each individual / employee and can be broadly broken down into objective events.

To achieve these career goals, it needs to start from an effort to understand themselves (self understanding). It is to the potential that exists in him, explore the things that interest him, to identify, map, and make plans or strategies for achieving career targets. The Guidance and Counseling profession in Indonesia has a quite central role in helping someone in their efforts to understand their capacity. This is based on several functions of Guidance and Counseling including the functions of understanding, development, maintenance, and distribution.

Career planning and development is one of the domains of Guidance and Counseling services. In the context of Guidance and Counseling services this is called Career Guidance. Career guidance is guidance in preparing to face the world of work, in choosing employment or positions and certain professions and equiping themselves to be ready to assume that position, and in adjusting to the various demands of the job fields entered [2]
The Indonesian Minister of National Education of Regulation Number 22 of 2006 concerning Content Standards for Primary and Secondary Education Units provides support to professional Guidance and Counseling to carry out student self-development activities. Selfdevelopment is not a subject that must be taught by the teacher. Self-development aims to provide opportunities for students to develop and express themselves according to the needs, talents, and interests of each student in accordance with school conditions. No exception students who also need self-identification efforts to be right in making career decisions in the future.

Attention and preparation to provide career assistance to the client population are distinguishing and unique characteristics for the counseling profession [3]. Career guidance according to Walgito ${ }^{[4]}$ aims to help clients in (1) Understanding and valuing themselves especially those related to abilities, interests, talents, attitudes, and ideals (2) Recognizing and understanding the value of himself and society (3) Knowing various types of work related to their potential (4) finding obstacles that may arise in the achievement of the career (5) planning for the future and find a career in life that is in harmony or in accordance.

The Ministry of Research and Technology released higher education statistics on the number of active students in Indonesia in 2017 reaching 6.924.511 students. In the same year, there were recorded students dropping out (DO) and or resigning in 195.176. Many factors were behind the drop out of students. In addition to the problem of cost, motivation and seriousness of students during the lecture process also become the background of the problem. Students who do not enjoy the lecture process and do not really live it will certainly be the main cause of study failure. This does not need to happen if students have careful preparation in planning studies according to their career potential and interests.

Nathan \& Hill explains that one of career decision making is ineffective self-presentation, which is usually related to poor self-esteem or lack of oral and written communication skills [4]. This indicates that an understanding of oneself becomes central in planning a career. Someone will have a comprehensive and useful selfimage in career decision making on the self-orientation he has understood. One of the success of one's career achievement is also determined by the belief in his ability to achieve career targets in his life or what is called selfefficacy career decisions. Sawitri assert that in various studies there are positive implications of exploration and 
commitment made based on exploration in various domains of life related to self-efficacy of career decisions [5]. This means that one's ability to explore themselves makes a positive contribution to career decision making.

Referring to the discussion above, selfdevelopment begins with the process of self-understanding assessment and identification of talents and interests explicitly into the work area or context of the Guidance and Counseling task. In addition to psychological testing, Guidance and Counseling practitioners are deemed necessary to provide non-test instruments to accommodate the identification process. The availability of web-based assessment instruments seems to be the most realistic recommendation in order to answer needs and adjust technological developments.

Researchers will develop non-test instruments to detect career interests based on the career theory of John L. Holland. The essence of Holland's therapy is that both people and environments can be described interms of their resemblance to six model, or theoretical types [6]. Furthermore, the instrument is packaged in a website that allows users to access the instrument through their smartphone. Assessment to detect career interests that are developed scientifically, and the ease of accessing them to the latest media was the main motivation of researchers in conducting research and development processes.

John Holland's theory was chosen as the basis for product development because the theory is most relevant to the assessment or detection of career interests compared to other career theories

\section{METHODS}

This paper is a conceptual script about the research and development plan that the researcher will undertake. The research model used is Research and Development (RnD). According to Sugiyono research and development method is research methods used to produce certain products and test the effectiveness of these products [7]. Research and development is a process or steps to develop a new product or improve existing products and can be accounted for. Implementation of research and development is done by several methods, namely descriptive, evaluative, and experimental methods.

In this research and development descriptive method is used in the initial survey to collect data about existing conditions. These conditions include: a) The condition of the products that already exist as a comparison or basic material, $b$ ) the condition of the user in this case are 590 students from 4 Faculties at Yogyakarta University of Technology who are randomly selected as respondents and research subjects, c) the conditions of supporting and inhibiting factors of development to the operation of the product produced.

Evaluative method is used to evaluate the process of testing the development of a product. Products are developed through a series of trials, and every evaluation activity is held, both results evaluation and process evaluation. Based on the findings of the trial, an improvement was made. The trial begins with the validation of media and material experts to perfect the product and evaluate the content of the material contained in the product. Then the product is tested on respondents (students) as users.

The experimental method is used to test the ability of the product produced. Even though the evaluation phase (measurement) has been carried out (measurement), the measurement is still in the framework of product development. In this study, the experimental method has not yet been carried out because research and development have only reached product creation and have not tested its effectiveness.

Research and development steps according to Sugiyono are; potential and problems, information gathering, product design, design validation, design improvement, product testing, product revision, trial use, product revision and mass product manufacturing [8]. This research was conducted only up to the final product revision stage after being tested for use.

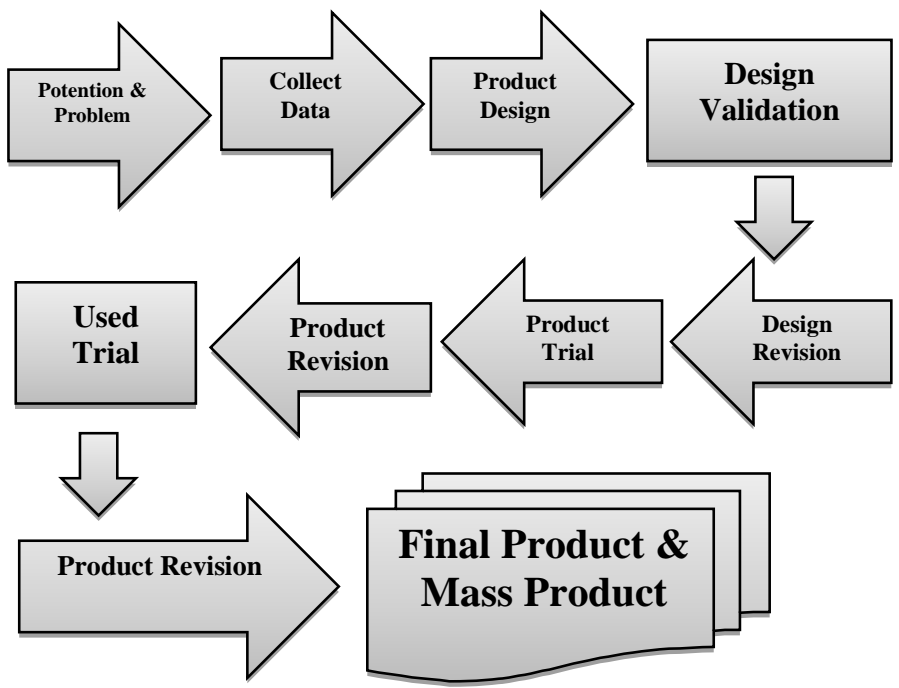

Fig. 1. Flowchart of Research

The respondents of this study were some students of Universitas Teknologi Yogyakarta who were randomly selected. The first survey of 590 students aimed to identify the needs and background of the problem. Researchers began to develop product designs or prototypes which were then validated by experts (media experts and material experts). Expert validation involves media experts in the web field to provide corrections and input on the appearance and operation of the product. Meanwhile academics and practitioners in the area of Guidance and Counseling will provide input regarding the content of the material contained in the product.

After the product developed was judged feasible by experts, the product was tested on students with established criteria according to the needs and research objectives. This study limits or sets the criteria for respondents (research subjects) to be involved, so the sampling technique used is purposive sampling. Students involved in product trials and usage trials were level 2 (minimum) students who have a cumulative achievement index (GPA) of less than 2.5 and a GPA of more than 3.5. Respondents are student representatives from each faculty who have predetermined cumulative achievement index criteria. Students with the 
above characteristics were chosen because the researchers wanted to measure the accuracy of the product, as well as test the hypothesis that academic achievement was determined by the suitability of career interests owned by students.

The number of students who will be involved in the product trial (limited trial) is 20, and will assess the feasibility of the product in terms of both content and media. After revision of the product in a limited trial is deemed sufficient, the trial is carried out on a larger group to assess the product in terms of usage. The trial use (large group trial) was conducted on 60 students who were also selected purposively.

The instruments used in this study were questionnaire and scale. The researcher developed a questionnaire with closed questions in the initial survey activity to find out the background and condition of the research subjects. While for the needs of product development and improvement, researchers adopted a feasibility scale in the form of a Likert from previous research and development with 5 intervals (Excellent (5), Good (4), Good Enough (3), Poor (2), and Very Poor (1)). The product feasibility scale is equipped with open-ended questions to provide descriptive input / suggestions for product perfection.

Result $=\frac{\text { Total Score Obtained }}{\text { Maximum Score }} \times 100 \%$

Fig. 2. Eligibility Results Formula

Product eligibility categories are formulated based on the following criteria [8]:

Table 1. Eligibility Classification

\begin{tabular}{|c|c|}
\hline Level of Feasibility / Effectiveness & Rating Classification \\
\hline $81 \%-100 \%$ & Excellent \\
\hline $61 \%-80 \%$ & Good \\
\hline $41 \%-60 \%$ & Good enough \\
\hline $21 \%-40 \%$ & Poor \\
\hline $0-20 \%$ & Very Poor \\
\hline
\end{tabular}

Students as users will provide an assessment of the developed media products. The aspects assessed include general components of the product, aspects of content, aspects of appearance, and aspects of product programming or operation

\section{RESULT AND DISCUSSION}

An initial survey of 590 respondents (students) of Yogyakarta University of Technology showed that there were $19.2 \%$ of students who had no understanding in career planning, and $48.3 \%$ did not have a full career preparation. These conditions indicate that students' study trips as part of the career process are carried out pragmatically without a mature orientation and strategy. Even $6.8 \%$ stated that they did not know the job prospects they obtained after graduating from their chosen major.
As many as $14.7 \%$ of respondents said the current chosen majors were not in accordance with their interests, and $29 \%$ of respondents stated that the chosen majors were not in accordance with their talents. $14.9 \%$ of respondents said the chosen majors at this time were not part of their career plans in the future, and $13.4 \%$ of respondents chose not to have a career in accordance with the discipline they were taking at the moment. Although the linearity of the suitability of the field of study with professions / jobs in the future is not 'fixed price', but the quality and professionalism of our work will be more awake its accountability if the educational background and the skills we take are in accordance with what we do.

Anne Roe (Winkel and Hastuti) involves the role of parents and their profession during the child's development [2]. This is a factor that also determines children's decision making in a career in the future. This is evidenced by data that shows $18.5 \%$ of respondents make parents the reason for choosing majors. Even $88.7 \%$ of respondents admitted that the choice of majors they took was coercive by parents. There is nothing wrong with parents' recommendations in choosing majors for their children, because parents base their life experiences as a reference for children. But what needs to be understood is that the study process is carried out by their children, and their children will be the ones who will face every challenge and obstacle during the study.

Career decision making that is not in accordance with individual conditions will be the cause of failure of the work or study process. This statement is supported by research findings regarding career maturity with employee turnover intentions. Research results show that the higher a person's career maturity, the lower his turnover intention, or conversely, the lower his career maturity, the higher his turnover intention[9]. Then everyone needs to have career maturity for every decision taken.

The data above provides background for researchers to offer solutions through research and development. Website becomes the most appropriate media choice to accommodate the product development that researchers will do. In addition to an attractive multimedia visualization, the website can be accessed easily through the device (smartphone) users.

The website is the whole web page contained in a domain that contains information [10]. Meanwhile, the definition of a Website according to Hendrianto is a collection of web pages that are related to other related files [11]. There is a page called the home page that is seen when someone visits the website. Starting from the home page the user can click the hyperlink to move to another page contained in the website. So it can be concluded that the website is a collection of pages that are connected to the internet that provides a collection of information and is packaged by connecting one file to another.

Website or site can be interpreted as a collection of pages that are used to display information, text, still or moving images, animation, sound, and or a combination of all of them, both static and dynamic that form a series of interrelated interlocking where each linked to page networks (hyperlinks) [12]. 
The process of identifying career interests in the product to be developed processes data in such a quantitative way that has been filled out by respondents to produce a qualitative analysis and recommendations. This process involves various elements so as to create a programming system. The definition of the system according to Scott (1996) and McLeod (2004) is a group of elements that are integrated with the same goal to achieve certain goals and consist of elements such as input (input), processing (processing), output (output) [13]. Another opinion about the definition states that the system is interrelated parts that operate together to achieve some goal or purpose. Broadly speaking there are two groups of systems approaches, namely systems approach which emphasizes more on the elements or groups defined as a network of interrelated procedures, gathered together to carry out an activity or complete a certain rule[14].

Data that were processed based on user contents were the accumulation of a series of activities that represent the interests of the filler's career. The definition of data according to McLeod is the fact that describes the existence of an event (event), the data consists of facts (facts) and numbers that are relatively meaningless to the user [13]. While the definition of information is the result of data processing so that it becomes an important form for the recipient and has a usefulness as a basis for making decisions that can be felt directly or indirectly in the future [15]. According to McLeod, information is data that is processed into a form that is more useful and more meaningful for those who receive it [13]. Another definition of information is data that has been processed into a form that is more meaningful to the recipient, and data is a reality that describes the events and real unity. An event is something that happens at a certain time [14].

The product developed is based on John L. Holland's theory which suggests six occupational environments and six personality types as the basis for someone to make appropriate career decisions. The occupational environments are:

a. Realistic (R) with characteristics like realistic careers such as, mechanical machinery, production planning, building construction, or marine engineering. They prefer to work with tools or machines that technically have work procedures or use clear tools.

b. Investigative (I) with a characteristic of favoring investigative activities and solving cases, such as: researchers, economists, management analysis, anthropologists, and biochemists, individuals with this type usually have abilities in the fields of mathematics and scholarship. They enjoy working alone, and are happy to solve scientific problems. They like to work with ideas rather than with people or equipment in general.

c. Artistic (A) with characteristics like work that involves elements of beauty (aesthetics), such as: architects, graphic editors, script editors, songwriters, interior experts, and designers. Individuals in this type generally have skills in the field of art, happy to create something new, have a high imagination. This characteristic is described as an individual who is imaginative, intuitive, emotional, idealistic, and independent.

d. Social (S) has characteristics like social careers such as; teacher, psychologist, personnel, teacher, or other social worker. Individuals with this type usually have good socialization skills, are interested in building relationships with humans, and are happy to help others. This type tends to prefer work related to humans rather than with equipment. In general, it can be described that individuals with this type are people who are friendly, warm, cooperative, friendly, sympathetic, patient, and caring.

e. Enterprising (E) likes an enterprise career, such as: marketing, financial planning, entrepreneurs, and lawyers. This type usually has good leadership skills and public speaking skills. They have the ability to influence others. Individuals of this type are portrayed as open, popular, social minded, confident, and ambitious.

f. Conventonal (C) has characteristics like conventional careers, such as: accountants, accountants, shopkeepers, and organizational positions. Individuals of this type enjoy working with regularity. In general, this type is described as like practical things, leadership, orderly, efficient and careful.

Holland illustrates the relationship of the six types above as hexagon where in the hexagon above can be represented by the letters that have been mentioned namely R, I, A, S, E, and $\mathrm{C}$.

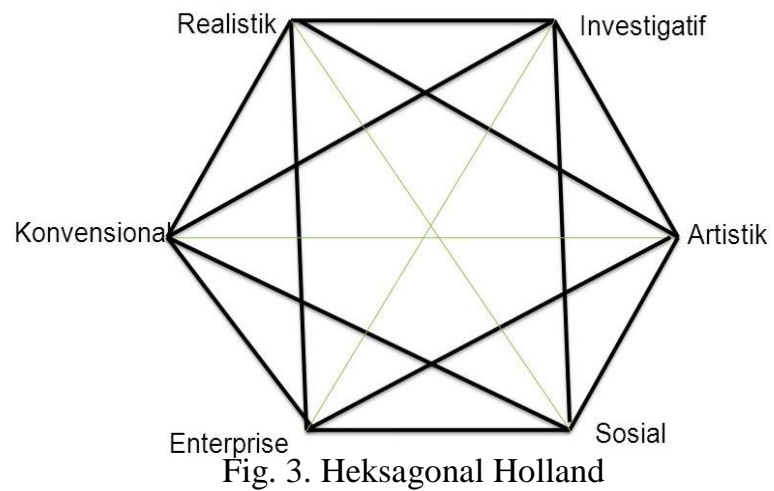

Holland introduces the concept of consistency constructed from Hexagonal Holland and refers to 32 relationships between the first and second letter codes, where Holland divides into three levels namely:

a. Consistence: when the first and second letters of the code are close together such as RI, IR, IA, AI, AF, FA, FE, $\mathrm{EF}, \mathrm{FC}, \mathrm{CE}, \mathrm{CR}$, and RC.

b. Moderatly Consistent: if between the first and second letters one type is embedded within a hexagon circle, such as: RA, AR, IS, SI, AE, EA, SC, CS, ER, RE

c. Inconsistent: where the first and second letters face each other in hexogens, such as: SR, RS, IE, EI, CA, and AC.

According to Holland's theory, a person is called inconsistent because he has a variety of experiences that also influence and strengthen the individual's capabilities. Whereas consistent individuals have internal stability and are not easily influenced. Holland also introduced the 
concept of congruence in which a person will obtain a career achievement that is far more optimal if they work in a field of work or position that has the same qualifications as the characteristics of their career interests.

Holland holds on to the belief, that an interest regarding work and occupation is the result of a combination of a person's life history and overall personality, so that certain interests eventually become a personality trait in the form of self-expression in the field of work, academic studies, core hobbies, various recreational activities and many other likes [2].

Researchers have designed the product design and started distributing it to students and students aged 14-21 years as a form of try out and design evaluation. The product overview is generally visualized through the following flowchart:

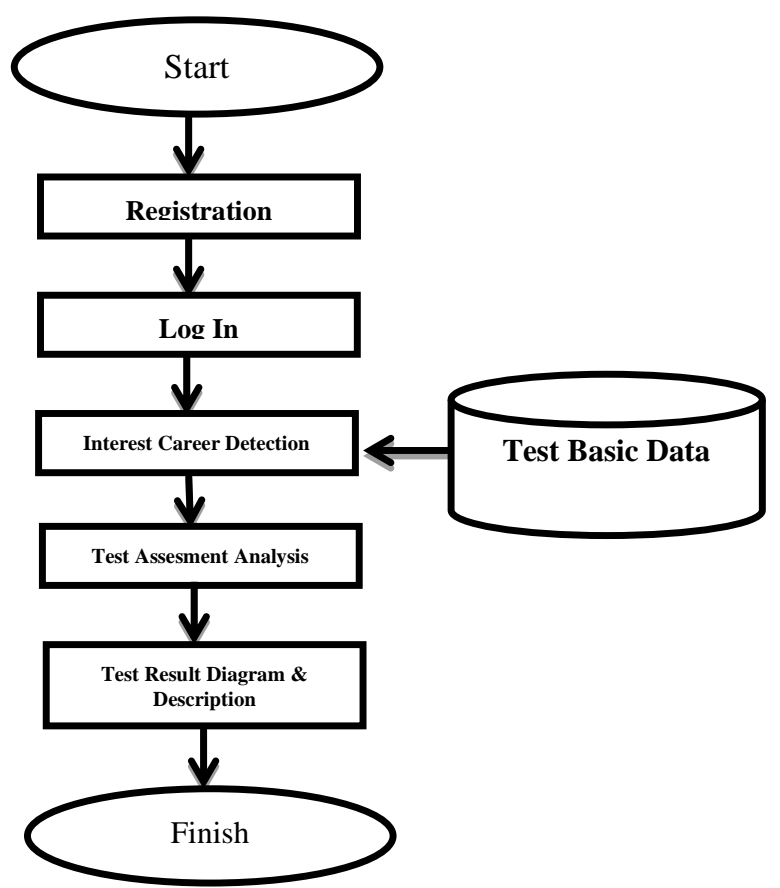

Fig.4. Product Development Flowchart

\section{CONCLUSION}

Career understanding is interpreted from the perspective of a job or the achievement of a position, the contribution of the surrounding environment, the experience that has been achieved, and the role of a person in the life of the environment or the people around him cannot be ignored.

The factors behind someone choosing or making a career decision are; intelligence abilities, talents, interests, attitudes, personality, values, hobbies, achievements, skills, use of leisure time, aspirations and knowledge of schools, work experience, work world knowledge, abilities and limitations in life, personal problems and limitations.

Success in career achievement is largely determined by a mature career planning process. Meanwhile career planning begins with an effort to understand themselves comprehensively. The research product to be developed helps users explore the characteristics of career interests that are useful in the career decision-making process. Matching the characteristics of career interests with the qualifications of a profession or position will be the main key to the success of the person's career achievement.

In accordance with the steps in the $\mathrm{RnD}$ research procedure, the researcher begins by identifying the potential and problems in the field. The high drop out rate for students in tertiary institutions becomes the rationale for researchers to identify deeper the causes. The first survey was conducted on UTY students to explore the background of study program decision making choices. The results show that there are still many students who do not have the maturity of career planning, thus affecting decision making.

The weakness of individuals in recognizing their potential and self interest are one of the factors in making mistakes in study programs in tertiary institutions. Instruments or tools that can help identify career interests are not widely available. Existing instruments and tools still have weaknesses in various aspects, namely technical use or implementation, product validity, completeness of material content and instrument depth, and final output or recommendations that are still shallow.

Furthermore, researchers have developed a career interest detection product design in the form of a website as a prototype that will be validated in advance by experts. Researchers only arrived at this stage until the manuscript was published. Researchers hope to get support from various parties during the research and development process to take place for the perfection and usefulness of the product being developed.

\section{REFERENCES}

[1] R. L. Mathis and J. H. Jackson, Manajemen Sumber Daya Manusia. Jakarta: Salemba Empat, 2002.

[2] Winkel, W.S and Hastuti, Sri M.M, "Bimbingan dan Konseling di Institusi Pendidikan” Media Abadi. Sleman Yogyakarta, 2013.

[3] Gibson, R.\& Mitchell Marianne H. "Bimbingan dan Konseling ed.7" Pustaka Pelajar. Yogyakarta. 2011

[4] Nathan Robert \& Linda Hill. Konseling Karir Edisi Kedua. Yogyakarta: Pustaka Pelajar, 2012.

[5] Sawitri, Dian R. "Model Keraguan Mengambil Keputusan Karir Pada Mahasiswa Tahun Pertama" vol. 13 no. 26. Universitas Islam Indonesia: Psikologika. 2008, pp. 41-47

[6] Nauta, Margaret M. "Holland's Theory of Vocational Choice and Adjusment" Brown, Steven D. \& Robert W. Wiley. USA, ed. 2nd, pp. 55-82, 2013

[7] Sugiyono. Statistik Untuk Penelitian. Bandung: Alfabeta. 2012

[8] Arikunto, Suharsimi. Prosedur Penelitian Suatu Pendekatan dan Praktek. Jakarta: Rineka Cipta. 2013

[9] Hanza, Sheriff R. \& Ingarianti, Tri M. "Kematangan Karir Dengan Intensi Turnover Pada Karyawan" vol. 3 no. 2. Uniersitas Muhammadyah Malang: Jurnal Ilmiah Psikologi Terapan. 2015, pp. $286-303$

[10] Yuhefizar, Mooduto, Rahmat Hidayat, "Cara Mudah Membngun Website Interaktif Menggunakan Content Management System" Joomla. Edisi Revisi, Jakarta. 2010.

[11] Hendrianto Dani, E, "Pembuatan Sistem Informasi Perpustakaan Berbasis Website Sekolah Menengah Pertama Negeri 1 Donorojo Kabupaten Pacitan", 4th ed., vol. 3. Indonesian Journal on Networking and Security, 2014, pp.57-64 
[12] Utama, Y. (2011). Sistem Informasi Berbasis Web Jurusan Sistem Informasi Fakultas Ilmu Komputer Universitas Sriwijaya. Jurnal Sistem Informasi (JSI), 3(2), 359-370. Retrieved from http://ejournal.unsri.ac.id/index.php/jsi/index

[13] Yakub. Pengantar Sistem Informasi. Yogyakarta: Graha Ilmu. 2012.
[14] Ladjamudin, A. Analisis dan Desain Sistem Informasi. Yogyakarta: Graha Ilmu. 2005.

[15] Edhy Sutanta. Sistem Basis Data. Yogyakarta: Graha Ilmu. 2004. 